beach. It is very rare in Saskatchewan, the only sheet in the Fraser Herbarium came from Great Sandy Lake (Hanson Lake Road). As to recognition, it is one of those limp submerged aquatics, in this case an annual rooted to the bottom, with opposite serrate linear leaves and inconspicuous oblong fruits some $2 \mathrm{~mm}$. long sessile and singly in the leafaxils. The point about this finding is that W. P. Fraser and students botanized Pike Lake thoroughly in the 1930's and did not get it. The plant is not all that inconspicuouschunks break off and are washed up on the beach, thus announcing its presence to those who are lookingand I do not think Fraser could have missed it. The alternative explanation is that Najas has come in since, perhaps since Pike Lake was made a provincial park. It is common in Eastern Canada.

Buchloe dactyloides (Nutt.) Engelm., the Buffalo Grass of the American short-grass plains, I had the good luck to find at Estevan, August 4, 1957 (Blue Jay 16, 20-21, 1958), as the first record in Saskatchewan. Another colony turned up this summer, also at Estevan, on SW 1/4 30-28 W2, some 2 miles NNW of the earlier discovery. This lot was growing around a stony depression on clayey prairie, of the sort which holds water only a few weeks in spring and soon dries up leaving cracked clay carrying a sparse annual vegetation rather than an aquatic flora of any sort. Associated species were Polygonum aviculare (native form), Plantago elongata, Schedonnardus, Poa secunda. Geologically the site was thin $\left(5^{\prime}-10^{\prime}\right)$ till over grey sandy clay of the Estevan beds of the Ravenscrag formation. The point is, the Buchloe was not growing in climax grassland at all but on a site, though usually dry, subject to just enough flooding to make the life of climax grasses like Stipa, Koeleria, Bouteloua, etc. impossible. The influence of bedrock shales may also play a part in rendering the soil more barren and thus making life tougher for climax grasses. The earlier location, SW $1 / 4$ 17-2-8 W2, a dry gumbo flat on the bottom of a valley tributary to the Souris River, also possessed the properties of rare flooding and bedrock shale influence. This restriction of Buchloe to a habitat which is effectively disturbed is doubtless due to being at the edge of its range, where it can survive only if freed of some of the competition. Further south it is a member, a dominant member, of a short-grass prairie community.

As an irrelevant sideline, the pothole in question had a little water in it on July 22 because of recent heavy rains. My attention was drawn to the Buchloe and its habitat by our truck getting stuck in this low gumbo spot, whereas we'd been passing over climax prairie, sodden though it was, without difficulty.

\title{
CROCUS NOTES FROM DAWSON CREEK
}

\section{By Dorothea Horton Calverley, Dawson Creek, B.C.}

The article on the Crocus Anemone in the September 1969 Blue Jay prompts me to add a note or two.

The super-abundance of the crocus in the spring of 1969 extended also into the Peace River country. Whole hillsides in the vicinity of Dawson Creek and out into the foothills of the Pine Valley gave from a distance the appearance of a scarf of delicate blue-orchid having been flung over them. Old-timers said that never before had anything like it been observed.

Whether the fact that the winter of 1968-69 was the coldest in memory had anything to do with it is an interesting question. During the two previous springs untimely and exceedingly heavy frosts in mid-May, after warm spells in April, froze even these super-hardy flowers so that, except in very few places, they produced no seeds. This year's flowering 
may have been a compensating effort.

During the winter of $1968-69$, there were no Chinook winds. The average temperatures during January at hourly intervals was $-1^{\circ} \mathrm{F}$ for as many years as the airport has existed. In 1969 it was $-26^{\circ}$. For 28 or 29 days the temperature never rose above $0^{\circ}$. One might suppose that such prolonged cold might affect the flowering shrubs. Not so. This observer has never seen, in 35 years, such shows of flowering currants, gooseberries, huckleberries, etc. Oddly, the fruit of Saskatoons persisted extraordinarily late in some places. We found an abundance of large sweet berries in mid-September long after the usual term of fruiting.

On the subject of white crocus: When the bridge over the Peace River at Taylor, B.C. fell down, the road was forced over a by-pass on a riverflat to the railway bridge up-river. There we found several clumps of "white" crocus. They were not "albino" forms because near the centre of the flower, the sepals were flushed with yellow. I have been told that occurrence of white crocus is fairly common along the Peace River.

Further, I found that crocus in abundance grew in the extremely sandy soil in the jack pine forests near Hudson's Hope. This was sur- prising to one who expected them to be at their best in the deep, grassy, virgin loam of the prairies. After submitting specimens to the provincial botanists at Victoria I discovered that these crocuses are of a different type, identified by Dr. Adam Szczawinski as Anemone patens (L) Ssp. multifidia (Pritzel) Zancels. From my further study of the plant, I gather that the crocuses at Hudson's Hope are related to Arctic varieties.

Concerning the White Crocus, Dr. Szczawinski notes that Dr. Moss in his Flora of Alberta lists it under the name Anemone patens L. var. wolfgangiana (Bess.) Koch, in which a "nearly white form may be found at that time (June, 1961 quoting Dr. Szczawinski "the White Crocus has been found in B.C. but localities and general distribution (were) still pretty vague.")

A special difficulty exists here in studying the crocus. The deer range in spring over the grassy places where the above crocuses abound. An old-time trapper's wife, Mrs. Durney, told me that the deer eat the flowers greedily when they first appear apparently as some sort of "tonic" or dietary necessity. Frequently where deer or cattle range (and children don't) one finds plants with flowers closely nipped off.

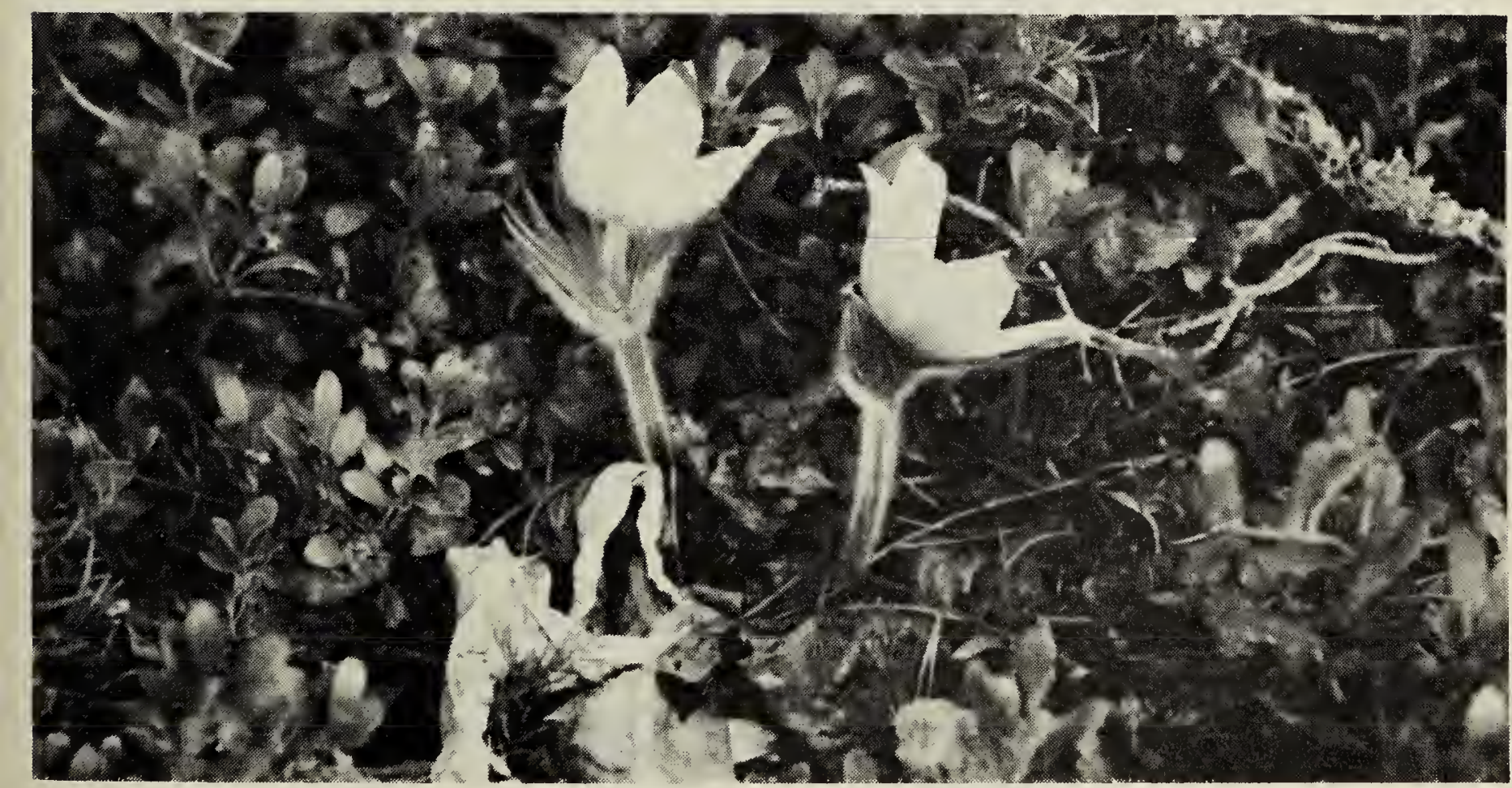

Crocus Anemone at the Pas, Manitoba

Photo by Robert A. Mitchell 